\title{
FINANCIALSTABILITY OF ENTERPRISE AS THE MAIN PRECONDITION FOR SUSTAINABLE DEVELOPMENT OF ECONOMY
}

\author{
Konstantins Cernavskis ${ }^{1}$
}

University of Latvia (Latvia)

\begin{abstract}
The problem of financial stability of a modern enterprise predestines a long-term development of state. The long-term development strategy-making concepts, binding to each member state, have been legislated in the European Union. A sustainable development is a balanced and socially responsible economic development subject to preservation of the environment and resources for the benefit of future generations. A national sustainable development plan prior to 2020 is required for each EU country. Under the development priorities situation typical to Baltic States, featuring a relative deficiency of mineral resources with some possibilities of development of high-end technologies, transit industry may be deemed the main priority. The enterprise financial stability concept is the main objective, regarded as a mandatory condition for ensuring a long-term and sustainable development as exemplified by the two renowned air carriers. The methods of scientific research most frequently applied in economics domain have been used: monographic, comparative, hierarchical and quantitative methods of financial ratios.
\end{abstract}

KEYWORDS: financial stability, activity, processes, compensatory mechanisms, sustainable development.

JEL CODES: G320, G390

\section{Introduction}

The economic instability existing nowadays under the crisis bailout circumstances inevitably affects business systems of all levels; therefore, any manager team should be ready for taking prompt actions of planning and process monitoring at the enterprise. The domain of finance is normally highlighted as one of the main fields at an enterprise, since the result to be achieved depends on quality, deadline, and volume of funding necessary.

By examining the notion of stability in the context of ensuring a sustainable and long-term development, the author of this article is underlining the necessity of investigating that concept and developing a new method of its application. The new enterprise financial system stabilization technique implies a partial disclaimer on generally-accepted elements and methods of anti-crisis financial management; it is based on a separate analysis of activity and processes running at an enterprise.

The purpose of this article is a research investigation of the origin and evolution of the concept of stability, as well as the development of an innovative technique of financial stabilization of enterprise to provide for a long-term and sustainable development of economy of a modern European country.

To attain the goal, the author has posed the tasks as follows:

- investigating the origin and the evolution of stability concept;

- determination of the role of stability in the process of ensuring a long-term sustainable development;

Konstantins Cernavskis - University of Latvia, Faculty of Economics and Management. Scientific field: corporate finance, financial management and innovative financial diagnostics of an enterprise.

E-mail: kon.cern@inbox.lv

Tel.: +37129448737. 
- developing the concept of financial stability at enterprise level;

- to work out the innovative model of financial stabilization of enterprise and its basic principles, drawing a comparison between two well-known European air transportation companies;

- validation of the model against the actual relevant data obtained from the two operating companies the Latvian "Air Baltic" and the Estonian "Estonian Air";

- interpretation of the model results, drawing conclusions, and working out proposals for improving the results of enterprise activities.

In the course of writing this article, the methods of scientific research most frequently applied in economics domain have been used. In the theoretical part, monographic, comparative, and hierarchical methods, as well as induction and deduction method, have been used. In the practical part, the official annual report data from the Register of Enterprises of Latvia and Estonia over a 10-year period have been used; moreover, quantitative methods of financial ratios, integral indices, the dynamic and structural analysis, as well as the qualitative method applying some elements of Gleiser's grounded theory have been used. The standard methods of scientific research are used: the comparative analysis, a graphic method, an induction method, a monographic method.

The conclusions and proposals put forward by the author as a result of the investigation research are practical concerns. The formulated proposals enable company management to work out a new method of achieving financial stabilization which, subject to particular characteristics of a specific enterprise, may be applied in the context of actual business activity.

\section{The background and evolution of the notion of stability}

The notion "stability" is derived from Latin. As translated from Latin, the term stabilis means steadiness and regularity. A stable object is characterized by such definitions as flat-footed, steady, firm, steadfast, safe, unchangeable, consistent, solid, inexorable, permanent, and constantly running (Dvorecky, 2011: 1). The majority of glossaries construe the term 'stability' through the aggregate of a number of synonyms only, not offering any definition. For instance, the Encyclopaedia Britannica defines the term 'stability' as a grade, a wear property, a capacity for retaining steadiness, hardness, and firmness, as well as a degree of hardness and a body's capability of getting back to its initial condition after having lost equilibrium state(An Encyclopeadia Britannica, 2011: 1). Lack of any general definition confirms that the term investigated has an exceptionally wide sense. Moreover, it has the property of functionality, i.e., the notion of stability may be applied to describe the functioning of various fields of science.

The notion of stability was used for the first time in ancient Rome, in first centuries AD, when it meant, first of all, safe existence of society; namely, the initial function of the definition pertained to a segment of military strategy. Later, in XV-XVI centuries, this notion was used at the beginning of the formation of Russian State, in tsarist days of Ivan the Terrible (The history of Russia of XVI century, 2011: 1). This time again, stability was connected with policy and strategic actions from the tsarist armed forces. In ancient Rome, stability was attributed to family values. According to the investigations made by Richard Suller, a historian from the Chicago University, it was exactly the history of ancient Rome that served as starting point for the formation of the core family values as an element of society's stability; those values haven't lost a bit of their relevance in modern social sciences (Saller, 2011: 1).

Therefore, one can come to the conclusion that stability had initially occurred in the sphere of social sciences and sciences describing society; this undoubtedly emphasizes the importance of the investigation of that notion exactly in this sphere.

Later, the term "stability" came to exact sciences as physics, for example. Already in the middle of XX century, there occur such notions as "Automatic stabilization", "Ideal stabilization", "stabilization variables" etc., aimed at attaining one and the same goal. Form that point of view stability of a system is the maintenance of a preset, time-constant value of one (or a few) controlled quantities, irrespective of any external 
and internal disturbing (de-stabilizing) impacts striving for deflecting the controlled variable from the preset value (The Large Soviet Encyclopaedia, 2011: 1). When analyzing the investigated term in trans-disciplinary context, the author has marked some definite interrelationship between various interpretations given by functional definitions of specific areas of knowledge, thus, enabling the author to formulate the method of searching the general definition.

Stemming from the definition given by the sociology dictionary, stability is a system's functional performance, keeping its own structure intact and maintaining balance (Antinazi, 2009: 1). Therefore, one can come to the conclusion that all the elements of that system should maintain equilibrium. The interaction between the subsystems is a continuous activity which can be expressed in the course of simulation through multifactor regressive function. As a result, having determined the coefficient value of the influence exercised by a separate factor upon the effective vector, one can filter out subsystems of low significance. The author believes that such an approach allows one to determine and identify functional pathologies of the system investigated.

\section{Stability as a foundation for long-term development}

The conditions of market development and stability at international level are provided by special political and economic institutions. The European Commission is, in particular, a modern international institute regulating the economic stability issues in the European Region. On holding World summit on SD - Guidance in preparing National SD strategy, the European Commission produced a legal document entitled COM/2001/0264 Communication from the Commission A Sustainable Europe for a Better World: A European Union Strategy for Sustainable Development, - regulating the procedure of working out long-term development strategies with respect to the countries of European Union (EUR-Lex Access to European Union Law, 2012: 1).

Each country develops those strategies independently, in compliance with the principles accepted. Those principles are aimed at attaining three goals: economic growth, social convergence, and environmental protection (EU Commission on sustainable development, 2011: 1). Attaining the goals posed means sustainable development and the long term-oriented growth of economies in trans-national aspect. Consequently, the prerequisites for ensuring a long-term development both of an individual state and an economic group of states are the provision of stability within the economies of those countries.

Various institutions are engaged in the provision of financial stability on an international scale. Financial Stability Board is one of those institutions. The association unites 64 agencies from 24 leading countries of the world. It includes central banks, Ministries of Finance, banking sector overseeing institutions, insurance agencies, accounting companies, and other international organizations. Among the member countries are USA, Argentina, BRICS, Japan, Germany, France, Canada and some other countries. The affiliated organizations include the World Bank, the European Commission, the Basel Committee on Banking Supervision (BCBS), and some others. On an international level, FSB is engaged in coordinating the work of national financial authorities; it unites national-level bodies responsible for financial stability of the principle subjects of those states: in the sphere of state finance, in the banking sector, and in business environment (Financial Stability Board Homepage, 2011: 1).

Business environment is the main segment of the investigation since it constitutes the major part of the entire economy of a state. An aspect describing the state of activities of a separate enterprise, the corresponding industry, and the economy as a whole is historical financial information highlighting the results of those activities. The aim of the high ranking managers is to find and establish this moment of optimum correlation between the owned and borrowed capital and as a result increase the company's value. 


\section{Financial sustainability of the enterprise as an important component of stability}

Financial sustainability in the modern economic space is used on a fairly wide scale: this term is used at all levels - from a separate household or an individual entrepreneur to global world finance systems and their activities.

Financial sustainability of a commercial agency is defined by law as solvency or capability of being liable for obligations assumed for a long time period. Financial stability is a component of the general stability of enterprise, the cash flow balance, the availability of resources allowing the agency to run its activities within a long time frame, including an efficient control of its equity and borrowed capital and providing for manufacture of products (Glossaries and Encyclopaedias on Academician, 2011: 1).

The above-quoted statement is confirmed by some works of foreign scientists as well. For instance, V. V. Bocharov believes management of equity and borrowed capital of company, as well as working out methods of the capital structure optimization, to be one of the most complicated problems to be solved in the course of management of corporate finance (Bocharov, 2001: 93). Those capital structure optimization methods were first suggested by Professor I. A. Blank in his papers published in 1988-2000. According to Blank's assumption, the optimal capital structure reflects such a ratio of equity and borrowed capital usage that provides for the most efficient relationship between profit ratios of the equity and the borrowed capital, which directly influences the increment of corporate value (Yensen, 2001: 21; Blank, 2011: 67; Kopitov, 2006: 148).

Some authors of various sources of theory of finance directly interconnect the notions "stability" and "solvency" fairly frequently. For instance, in the opinion of M.Yensen who had introduced the notion of a free cash flow index for scientific use in the 1980-ies to show which cash resources may potentially be placed at the disposal of company owners (Yensen, 2001: 22), one can conclude that the company may be deemed financially stable if the free cash flow is available, and vice versa.

However, the notion of solvency denoting the financial standing of company enabling the latter to pay off all of its debts at maturity (Financial Glossary, 2012: 1; Lozovsky, 2007: 88) is only a constituent part of corporate finance stability. Irrespective of company activity profile, three types of cash flow are inherent in any company operating in market environment. Those are cash flows obtained from the main activities, investment operations, and financial activities of company. In the aggregate, all those flows characterize the general 'wave' of flows of free cash flow for owners. M. Yensen defines that flow as FCFE (Free Cash Flows to Equity) index.

According to the conclusions drawn by M. Yensen, positive values of FCFE index demonstrate business strength while positive dynamics of FCFE can show the business stability. On the contrary, negative values of FCFE illustrate weakness of business and the dependence of company's operations on borrowed money mobilized. Negative values of FCFE may occur due to instability of the main flow, i.e. the flow obtained from operational activities, and also due to the necessity of major investments and large repayments of debts. Negative flow of money resources free to owner attests exactly to its instability: the company being in such a condition can develop only if supported by some major cash flow from funding.

From the above-quoted principle of free cash flow shaping, it is quite obvious that this criterion can be regarded as an integral index of stability of a modern commercial agency.

The possibility of using that index when analyzing the company standing on market should be the primary goal of financial experts; however, to determine the company standing, a number of tasks should be accomplished to estimate the three above-stated components: operating activities, investment operations, and financial activity. This expert investigation is practically accomplished through using some methods and procedures of the classical financial analysis.

\section{Methodology of stage-wise analysis of enterprise stabilization}

The conducted investigation of theoretical aspects of financial analysis and the enterprise financial condition assessment methods and procedures predetermined the necessity of working out a methodology for stage-wise stabilization procedure. The procedure is necessary to analyze the factual evidence to be found 
in the second chapter. The procedure suggested is based on the main principles of assessment of financial condition, rapidity changes, comparative analysis, and ratios sensitivity analysis.

The procedure is a complex, multi-level plan of analysis of enterprise's finance, consisting of three main stages.

The first stage is the above-mentioned Identification; this is a preliminary analysis of enterprise activities. At that stage, the principal methods and approaches of financial analysis and ratio calculation theory are used, such as the balance assets and liabilities profile, liquidity, profitability, assets and liabilities turnover; furthermore, dynamic and structural analysis of fiscal accounting is performed - both with respect to the enterprise itself and against the general background of the entire industry. The identification process is run based on the financial data history; it reflects the results attained in the past. At the same time, however, it can not rule out the possibility of constructing trends and forecasting financial processes of the enterprise.

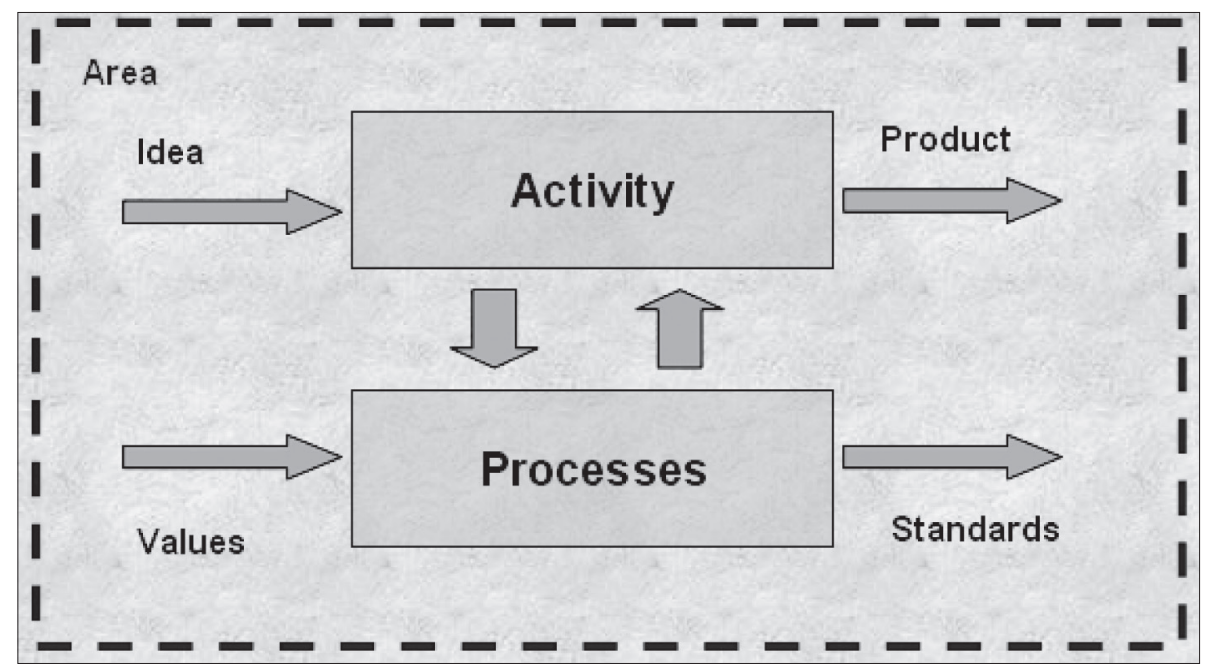

Figure 1. The schematic model of enterprise activity and processes Source: created by author

At this point, it is necessary to determine the difference between "activity" and "processes" within the framework of the procedure developed. In the opinion of L. Faingloz, activity of an enterprise and management processes are different categories. An effective support of activities claims for a sequence of actions implying conversion of the idea generated into end product. Consequently, such a conversion is aimed at working out some activity service mechanisms based on its one-to-one correspondence to the unique process (Faingloz, 2011: 186; Kopitov, 2011: 200). From all that has been said it follows that the activity and the processes are running apart from each other but they are continuously influencing each other at the same time, which attests to the necessity of investigating those categories and their mutual influence separately but within the framework of a definite system.

Fig. 2 shows the activity and processes interaction scheme at local enterprise level under a definite business environment.

Within the framework of the investigation, it is assumed that 'activity' is the total of the economic activities of enterprise, aimed at converting the idea into the end product, - while 'process' is a response of the financial condition of enterprise to interference from management's decisions.

If the results obtained at the identification stage attest to the fact that the enterprise is stable but, at the same time, interference of some significant processes takes place as a result of decisions taken by management - a deregulation of financial stability of the enterprise takes place. This phenomenon is described by the second stage of the procedure - systematization.

At the systematization stage, processes leading to financial deregulation of activities are analyzed. Those are unique with respect to each enterprise, but, at the same time, they have some definite common features, 


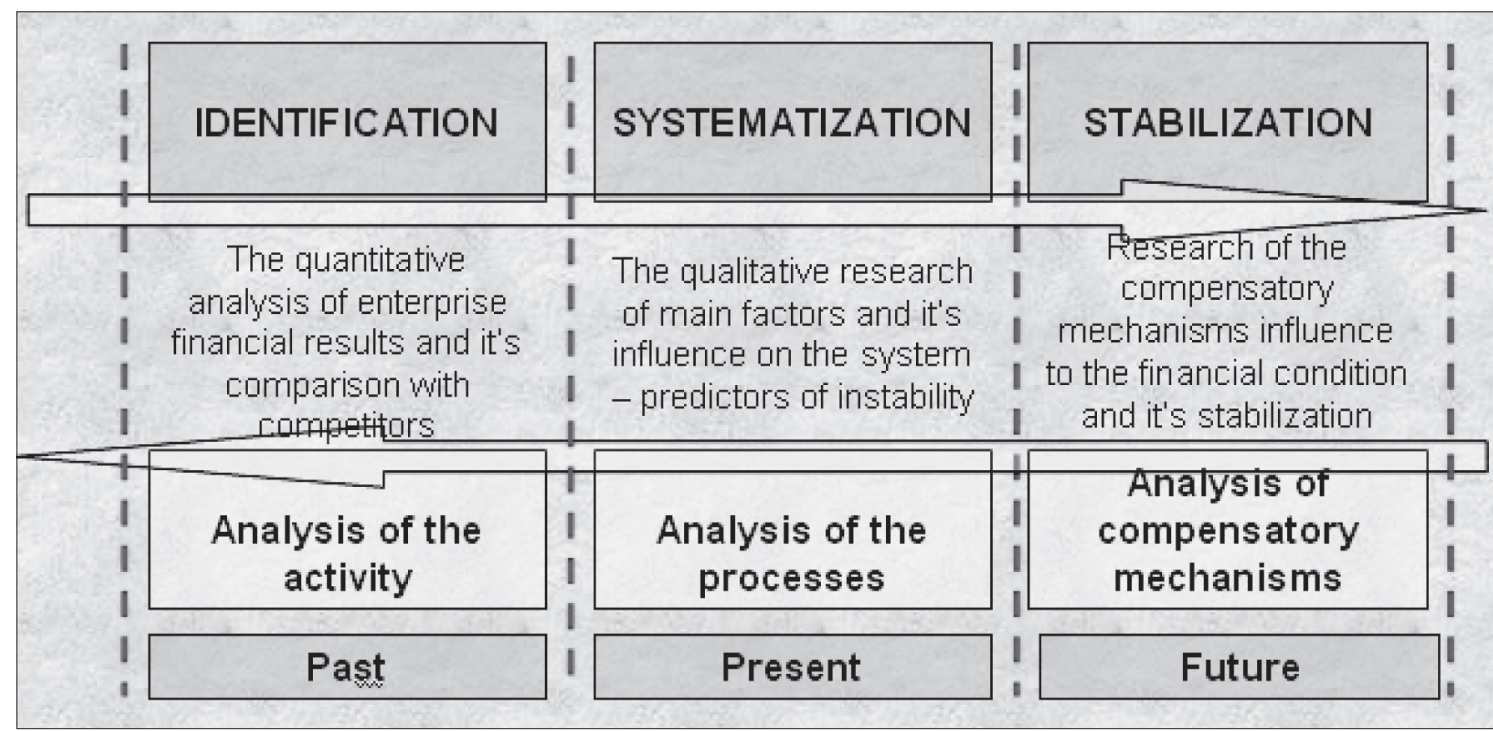

Figure 2. The procedure of stage-wise analysis of enterprise stabilization

Source: created by author

based on which one can develop a model and define the factors withdrawing the system from the steady-stated condition. Therefore, conducting case-studies of different enterprises from various branches may yield different results but similar tendencies. It is exactly at this stage that inductive selection or systematization of the criteria of enterprise financial stability takes place. The systematization process is run on the basis of relevant (up-to-date) data and it reflects the results achieved at the moment of the analysis or in the recent past.

The third stage of the procedure is stabilization. At that stage, inverse processes aimed at transferring or returning the enterprise financial system to the state of stability are searched and assessed. The author defines those anti-processes as compensatory mechanisms. The concept of compensatory mechanisms implies that each process bringing a financial system out of the state of stability may be opposed by another process returning system to that state. And the system being unstable means that no compensatory mechanisms are activated. There may be a few reasons; however, the main reason is the enterprise managerial staff ignorance as to the existence of such possibilities. At the stage of stabilization, simulation of activity-compensating inverse processes is performed; moreover, continuous controlling of sensitivity of identified ratios obtained at the first stage is made. Comparative analysis is performed to reveal the necessity of getting back to the previous stages of analysis. The stabilization process is run on the basis of relevant and prognostic data, and it reflects the future-oriented results of the activity of enterprise investigated.

\section{Determination of financial stability level as exemplified by a comparison between two carriers}

Within the framework of the practical approval of stage-wise analysis of financial stabilization, some financial information was used, describing the activity of two renowned carriers: the Latvian air carrier "air Baltic" and the Estonian "Estonian Air".

The factual evidence investigation period is 10 years: from 2001 to 2010. In terms of duration, that period corresponds to the duration of an intermediate-term business cycle, and, in terms of the theory of statistical analysis, the period is deemed to be quite sufficient for revealing trend dependencies and making forecasts (Kaplan, 2006: 44; Norton, 2006: 45).

The identification stage yielded some results illustrating the earnings records from the companies investigated. 


\section{Profits dynamics}

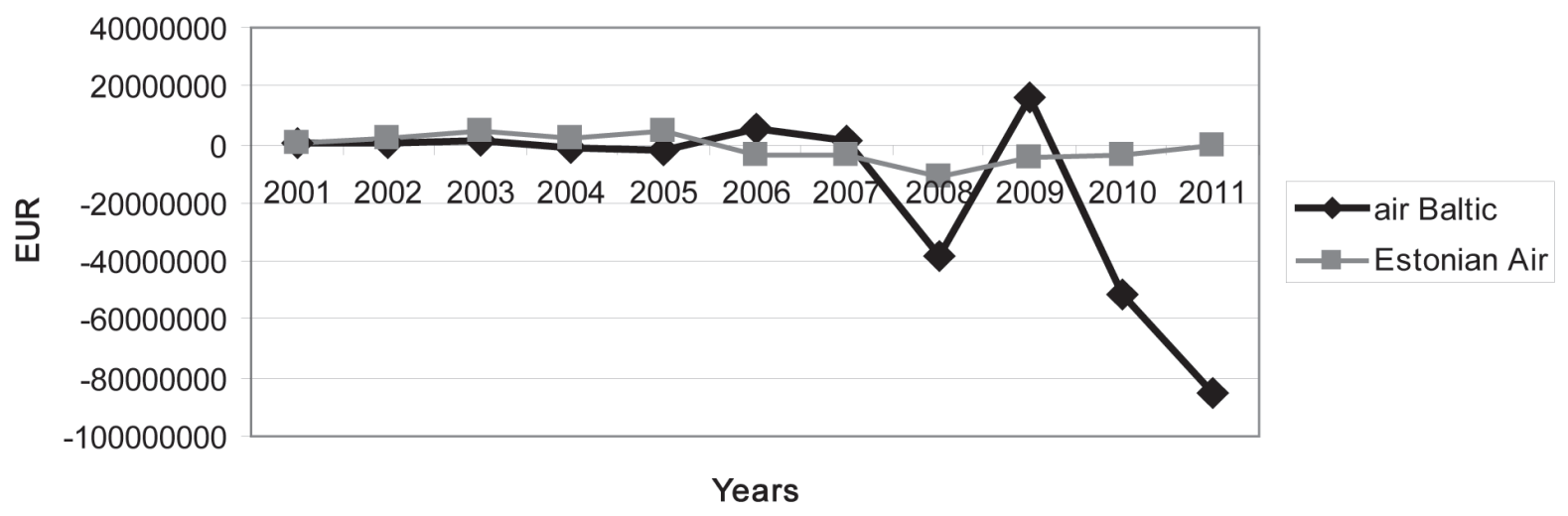

Figure 3. AIR BALTIC and ESTONIAN AIR profit dynamics comparison Source: created by author, using company's official financial reporting data

The trend differences are visualized distinctly: with respect to the Estonian company, the trend is positive while with regard to the Latvian company it is dramatically negative; an incommensurable loss of profit has been recorded from 2008 to 2011 year-on-year.

The author performing analysis through the ratio-based method has revealed the fact allowing one to claim that, if a company is running at a loss, a number of indices lose their economic sense; consequently, those indices are unfit for being used in this situation. For example, such business activity indices as commercial and financial profitability, a number of structural indices of capital, and the indices of balance and leverage do not fully reflect the reality with respect to an unprofitable company without certain assumptions. Moreover, any forecasting of rapidity changes by using standard statistical methods becomes impossible without using a well-balanced method, according to which, equilibrium between quantitative and qualitative investigation methods is to be found (Bryman, 2008: 54).

To eliminate the above-stated drawback inherent in financial analysis, the author suggests that some integral or integrated indices of financial activity should be used, commensurate with absolute values of property and funding sources. This method of analytical comparison may be presented in the form of two groups of identifiers:

- The integral (integrated) indices: possibility of bankruptcy, sustainable growth pace, and a free cash flow.

- The absolute values of property, financial results, and funding sources: assets, turnover, profit, equity capital, and total value of debt.

At the identification stage, some results have also been obtained describing the tendencies of bankruptcy possibility dynamics calculated according to the technique developed by E. Altman, and the comparison of free cash flow of the air carriers investigated.

It is obvious from the graph that the possibility of insolvency faced by the Latvian company is much higher than that of the Estonian counterpart. However, the free cash flow dynamics is negative with respect to both enterprises, and it has similar tendencies (Fig. 4). 


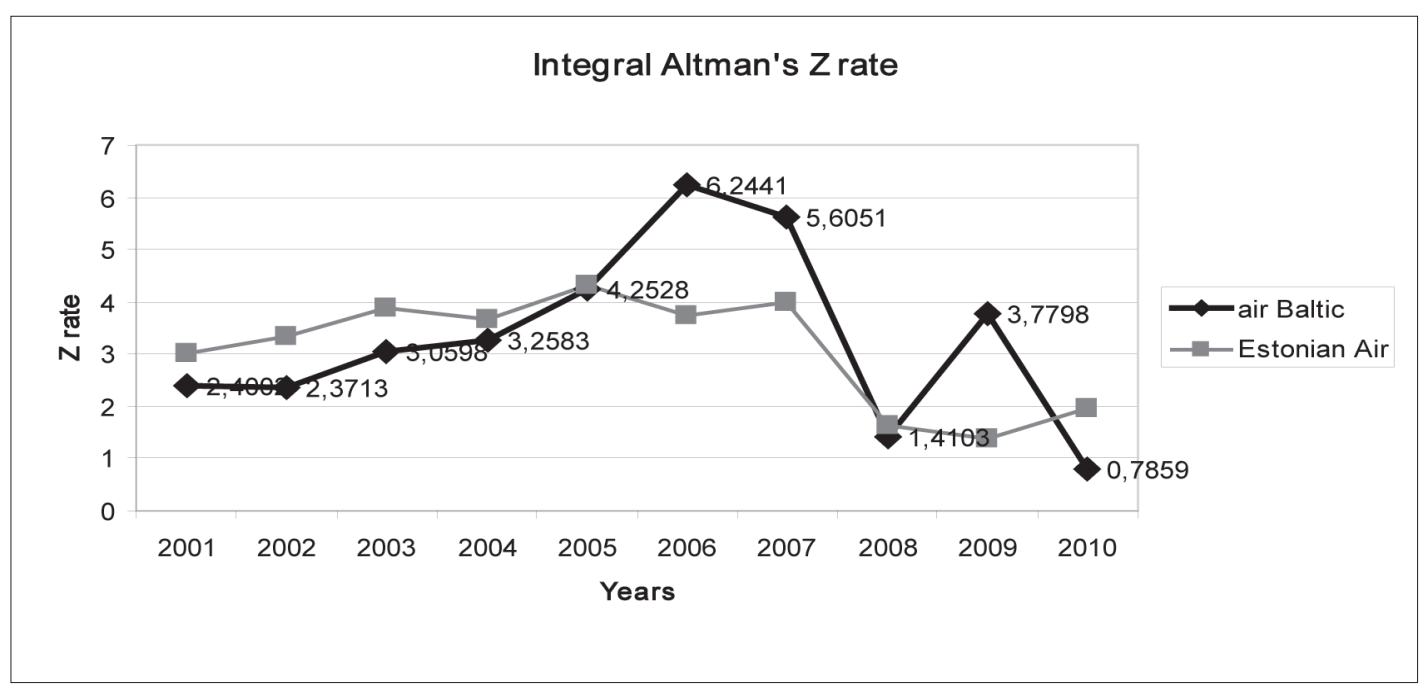

Figure 4. AIR BALTIC and ESTONIAN AIR bankruptcy probability dynamics comparison Source: created by author, using company's official financial reporting data

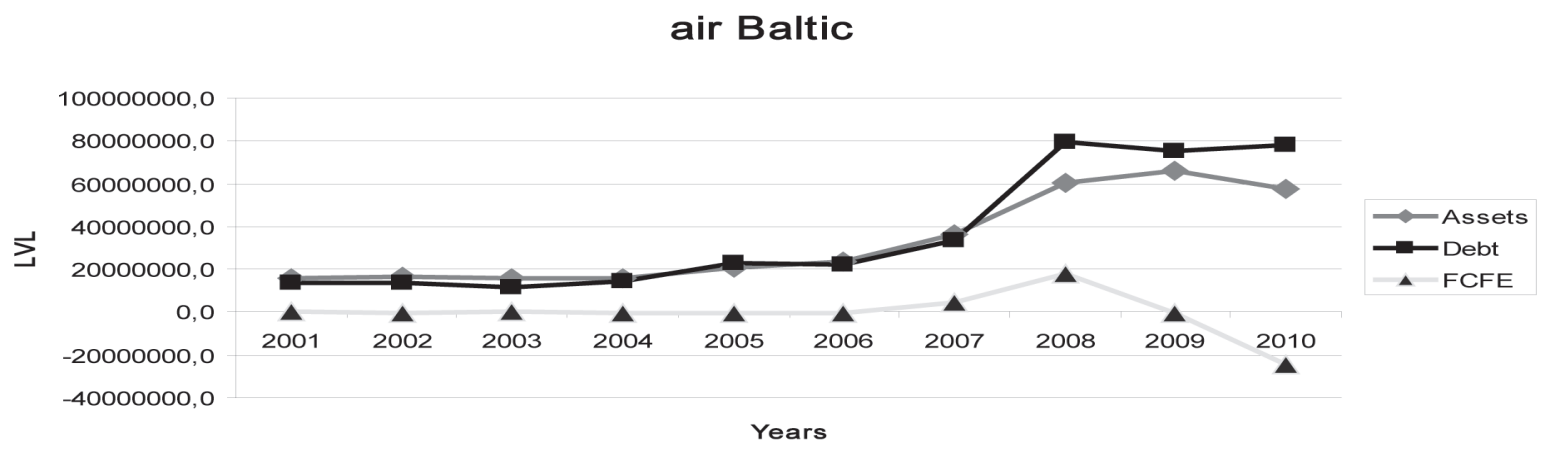

Figure 5. AIR BALTIC FCFE index and property comparison

Source: created by author, using company's official financial reporting data

To scale those indices against the efficiency of property change, the assets and gross debt change dynamics is assessed, since similar tendencies of negative cash flow may attest to making investments into the upgrading of the aircraft fleet and the park of other fixed assets.

As in the case with the Latvian company, the last upgrading of the aircraft fleet was recorded in 2008; moreover, a major change of the capital structure was recorded - an incommensurably large credit was received in 2008. The Creditor is JSC AS "Latvijas Krājbanka" - a bank currently insolvent. In the process of financial identification of the Latvian company, two facts have been revealed - the loan was disbursed without a preliminary assessment of financial results of the company (which experienced losses in 2008).

Moreover, as a result of the loan, which is not covered by the grand total of assets (as is seen from Fig. 5) - the free cash flow of the owners should not have dropped so abruptly. Unlike the Latvian Company, the Estonian counterpart made the last investments into the aircraft fleet in 2010; however, that was accomplished at the expense of the inner potential of the agency, whereupon the drop of the free cash flow may be deemed justified. 


\section{Estonian Air}

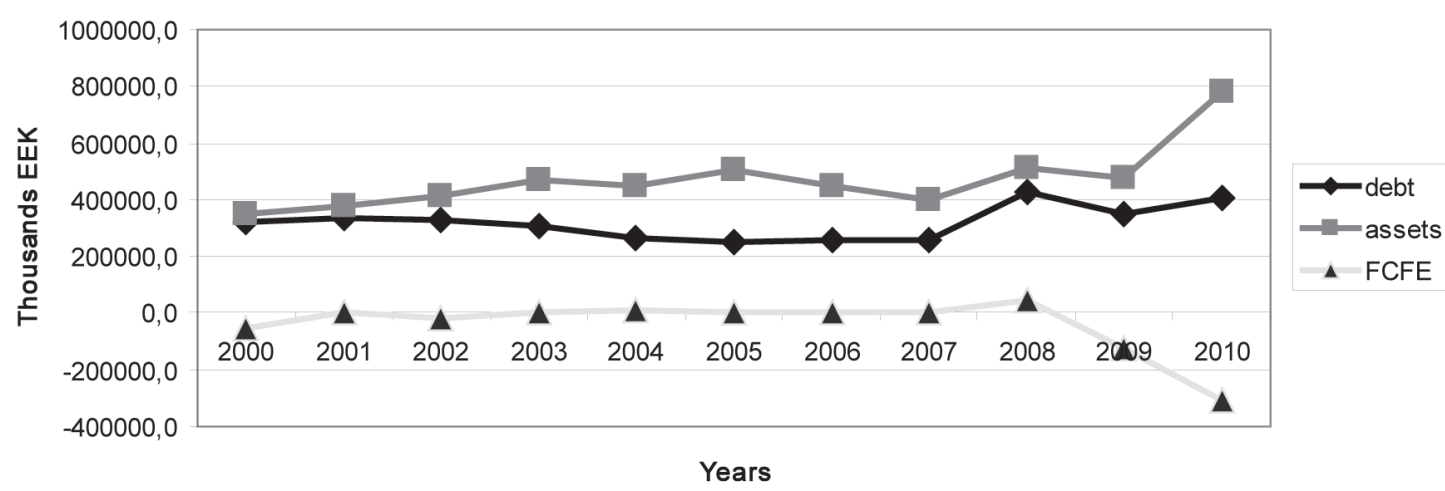

Figure 6. ESTONIAN AIR FCFE index and property comparison

Source: created by author, using company's official financial reporting data

This situation attests to uncertainty and financial instability observed in the activity run by the Latvian company as against to its Estonian counterpart. According to the 'imbalance quadrants' model, in order to turn the financial condition of those air carriers from the instability zone to the stability zone, it is necessary to investigate and offer some compensatory mechanisms to be used, which would ensure balance of power of the system, thus enabling one to attain stability.

\section{Conclusions}

The approach and the stage-wise stabilization procedure examined in this article are fundamental concepts of the problem of financial stability of enterprise. This scientific approach is innovative since it has not actually been investigated and used to stabilize an enterprise. Moreover, unlike the generally accepted qualitative methods of financial analysis which are insufficient for making managerial decisions - this approach provides for a simultaneous balanced use both of qualitative and quantitative investigation methods.

The author investigating some items of operation of renowned European air carriers at system analysis level, has put forward a hypothesis stating that the activity and the processes at an enterprise level are characterized by altogether different conceptual interpretation. Based on the model suggested, according to which, an activity reflects the conversion of an idea and a resource into end product, while a process describes that activity through some definite values and norms - the author has come to the conclusions as follows:

- Activity and processes at enterprise level should be investigated not jointly and not separately but rather as elements interconnected within the framework of a definite system;

- According to system analysis theory, a system investigated is a complex system since some completely incompatible factors exist among its elements;

- As a result of interaction, elements of a system can bring the system into two states: stability (if the internal force vectors are directed so as equilibrium is provided) or instability (if the internal force vectors provide for disequilibrium, i.e., some factors dominate over the others);

- The stability assessment is made according to the "disequilibrium quadrants" model suggested by the author, uniting both quantitative and qualitative criteria, with the model serving as an efficient support for making managerial decisions;

- An assessment of financial results of the activities run by the two renowned companies was made by applying the above-stated procedure; as a result, an essential instability of the financial system of the Latvian company as opposed to the Estonian one was stated. The fact is proved by the calculated indices of bankruptcy possibility, forecasted sustainable growth, and free cash flow. However, the fol- 
lowing processes have rendered a negative impact on the activity of both enterprises: loss of turnover, loss of profit, loss of a part of equity capital, and the joint debt increase.

According to the above-stated conclusions, the author has put the following proposals based on the task of the third part of the procedure - with the view of stabilizing the activity:

- The management of the Latvian enterprise should state and systemize the processes withdrawing the company's activity from the state of stability; in this case, this implies revision and revaluation of the capital balance to cover the borrowed funds by using the company's own assets;

- The management of the Estonian enterprise should determine the principal compensatory mechanisms precluding systematic loss of profit and free cash flow;

- The analysis and planning departments of both enterprises should apply the multiple procedure of stage-wise stabilization of the financial system; so far as the compensatory steps are taken by the management, a repeated identification of the enterprise should be made not less than once in a quarter;

- When analyzing factor sensitivity, the analysis and planning departments of both enterprises should use relevant data on changes of external economic environment - both of the country of their own and the partner states;

- The management of the two enterprises should check the degree of financial stability of competitors against the background of the competitive industry, using the "disequilibrium quadrants" model, paying special attention to problematic agencies, since the prerequisites for a correct support of managerial decisions work more actively exactly in instable systems.

Form all that has been said it follows that an enterprise achieving financial stability of its activities passes through the stage-wise procedure of stabilization. So far as individual stages are passed on the way from the state of instability to the state of stability, certain changes take place at the scale level. From a loss of equity capital, one can return to loss of turnover only, having retained property. From a loss of turnover, one can return to loss profit, having preserved the rate of economic growth. Finally, from a loss of profit, one can return to free cash flows for owners, to the aircraft fleet development, an efficient implementation of investment projects, and creation of economic value. The enterprise is capable of passing from economic value of business to the highest surge of development - social responsiveness.

Creation of economic value of business is a result of managerial activity; the procedure suggested by the author provides exactly for the support of managerial decisions. Sustainable development, in its turn, is the goal of a long-term sustainable development of State confirmed by European legislation.

With the aid of the financial stability provision model suggested by the author, the management of any European enterprise is capable of achieving stage-wise stabilization. Everything depends on the goals and the competence of management proper - whether the management will be capable of passing all the stages of the procedure sequentially or it will still prefer misleading, customary, and "easier" methods.

\section{References}

An Encyclopeadia Britannica Company. (2012). Merriam Webster Dictionary. Web resource. Available at: http://www. merriam-webster.com/dictionary/stability

Antinazi. (2009). The Encyclopaedia of sociology. Web resource. Available at: http://dic.academic.ru/dic.nsf/socio/3 918/\%D0\%A1\%D0\%A2\%D0\%90\%D0\%91\%D0\%98\%D0\%9B\%D0\%AC\%D0\%9D\%D0\%9E\%D0\%A1\%D0\%A $2 \% \mathrm{D} 0 \% \mathrm{AC}$

Blank, I. A. (2011). Finance resource management. Moscow: Omega-L.

Bocharov, V. V. (2001). Corporate finance. St. Petersburg: Peter.

Bryman, A. (2008). Social Research Methods. 3rd edit. Oxford: Oxford University Press.

Cokins, G. (2008). Performance management Finding the missing pieces (To close the intelligence gap). John Willey $\&$ Sons Inc, SAS: The power to know.

Dvorecky, I. H. (2011). The general latin-russian dictionary. Web resource. Available at: http://linguaeterna.com/vocabula/show.php?n=42895 
EU Commission on sustainable development acting as the preparatory commitee for the World summit on SD. (2011). Guidance in preparing National SD strategy: Managing Sustainable Development in the New Millenium. Web resource. Available at: http://www.un.org/esa/sustdev/publications/nsds_guidance.pdf

EU Financial Stability Board Homepage: Overview. Web resource. Available at: http://www.financialstabilityboard. org/about/overview.htm

EUR-Lex Access to European Union Law. (2011). Web-resource. Available at: http://eur-lex.europa.eu/LexUriServ/ LexUriServ.do?uri=CELEX:52001DC0264:EN:NOT

Faingloz, L., Kopitov, R. (2011). Investigation of Factors Influencing Logistic Activities. Proceedings of the $11^{\text {th }}$ International Conference "Reliability and Statistics in Transportation and Communication”. Riga: TSI.

Glossaries and Encyclopaedias on Academician. (2011). Web resource. Available at: http://dic.academic.ru/dic.nsf/ ruwiki/695587

Kaplan, S. R., Norton, P. D. (2006). Alignment using the balanced Scoreland to create corporate synergies. Boston, Massachusetts: Harvard Business School Press.

Kopitov, R. A. (2006). Finance management. Riga: Transport and Telecommunication Institute.

Lozovsky, L. S., Rayzberg, B. A., Starodubceva, E. B. (2007). Modern economic dictionary. Moscow: Infra-M.

Saller, R. (2011). Family Values in Ancient Rome. Web resource. Available at: http://fathom.lib.uchicago. edu/1/777777121908/

The history of Russia of XVI century. Web resource. Available at: http://ote4estvo.ru/kratkaya-istoriya-rossii/627-istoriya-rossii-16-veka.html

The Large Soviet Encyclopaedia. (2012). Web resource. Available at: http://bse.sci-lib.com/article105650.html

The Register of enterprises of Republic of Latvia Database. Financial reports of AS “AIR Baltic Corporation”. Web resource. Available at: http://www.ur.gov.lv and http://www.lursoft.lv

The Register of enterprises of Republic of Estonia Database. Financial reports of AS "ESTONIAN AIR”. Web resource. Available at: http://ariregister.rik.ee and http://www.rik.ee/e-ariregister.

\title{
VERSLO FINANSINIS STABILUMAS, KAIP ESMINÉ DARNAUS EKONOMIKOS VYSTYMOSI PRIELAIDA
}

\author{
Konstantins CeRnavsKis \\ Latvijos universitetas (Latvija)
}

\section{Santrauka}

Modernioms organizacijoms būdingas finansinio stabilumo nebuvimas lemia ilgalaikị valstybès vystymąsi. Europos Sajungoje sukurtos ilgalaikio vystymosi strategijos kūrimo koncepcijos, privalomos visoms šalims narèms. Darnus vystymasis - tai socialiai atsakingas vystymasis, nukreiptas i aplinkos ir išteklių išsaugojimą ateities kartoms. Iki 2020 metų kiekviena ES šalis nare privalo parengti darnaus vystymosi strategiją. Baltijos šalims būdingi vystymosi prioritetai nulemti gamtos išteklių trūkumo, galimybių plètoti aukštąsias technologijas ir tranzitą. İmonių finansinis stabilumas yra pagrindinis prioritetas, laikytinas būtina sąlyga ilgalaikiam darniam vystymuisi užtikrinti, tai iliustruojama dviejų žinomų oro transporto bendrovių pavyzdžiu. Šiame straipsnyje taikyti ekonomikos moksle populiariausi metodai: lyginamasis, hierarchinis ir kiekybinis finansinių proporcijų.

PAGRINDINIAI ŽODŽIAI: finansinis stabilumas, veikla, procesai, kompensavimo mechanizmai, darnus vystymasis.

JEL KODAI: G320, G390 